\title{
Dynamics of gamma diversity and abundance of diurnal butterflies (Lepidoptera, Papilionoformes) in the Nizhny Novgorod Region (Russia) under anthropogenic changes in landscapes over the last hundred years
}

\author{
Stanislav K. Korb ${ }^{\circ}$
}

Russian Entomological Society, Nizhny Novgorod Branch, PO Box 97, Nizhny Novgorod, 603009 Russia stanislavkorb@list.ru

Received: 09.10.2021

Revised: 05.11.2021

Accepted: 06.11.2021

Published online: 16.11.2021

DOI: $10.23859 /$ estr-211009

UDC 595.789

Translated by D.M. Martynova

\begin{abstract}
The hundred-year dynamics of gamma diversity and butterflies' abundance have been assessed for the first time in Russia for the Nizhny Novgorod Region. According to analyzed data, we forecast that no significant change in the number of 104 species of butterflies is expected, the number of 33 species in the near future is likely to increase, and the number of 11 species will continue to decline in the near future. A decrease in abundance of 23 steppe and arcto-boreal species is also expected. The reasons for the decrease in the number of species are considered, supported by the long-term monitoring dataset. Extrapolation of our conclusions for Russian regions with similar conditions (Kirov, Ivanovsk, Vladimir, Kostroma, Penza, and Ulyanovsk regions and the Republics of Mari El, Chuvash, and Mordovia), taking into account the natural conditions of these areas, seems applicable and promising.
\end{abstract}

Keywords: diurnal butterflies, Volga River region, fauna, historical perspective.

To cite this article. Korb, S.K., 2021. Dynamics of gamma diversity and abundance of diurnal butterflies (Lepidoptera, Papilionoformes) in the Nizhny Novgorod Region (Russia) under anthropogenic changes in landscapes over the last hundred years. Ecosystem Transformation 4 (4), 32-41. https://doi.org/10.23859/estr-211009

\section{Introduction}

The study of the dynamics of species, population(s), or entire fauna is a core of any ecological research. The study of biodiversity without assessing its dynamics is not informative enough, since the efforts of mankind to preserve biodiversity without appropriate theoretical and practical research are ineffective. The last means that the primary study task is the development of these issues in the perspective of global anthropogenic changes in landscapes.
The Nizhny Novgorod Region is located in the temperate zone of the European part of Russia, at the junction of two natural zones (forest and foreststeppe), belonging to the Volga Federal District of Russia. The Volga River itself is a border between these natural zones. The area is slightly elongated in the latitudinal direction; its length from north to south is about $400 \mathrm{~km}$, from west to east, about $300 \mathrm{~km}$ (in the widest southern part). The main differences in climate are manifested from the north to the south, i.e., 
between the Trans-Volga Region (woodlands) and the elevated right bank of the Volga River (steppes).

Fauna of diurnal butterflies of the Nizhny Novgorod Region remained poorly studied until the end of the $X X$ century. At the beginning of the $X X$ century, A.A. Yakhontov (1906) has published the first article devoted to the daytime butterflies of the region. This publication was considered as a starting point for studying the dynamics of the fauna. Almost a century later, a list of Lepidoptera of the Nizhny Novgorod Region was published by S.S. Chetverikov (1993). This list was actually restored by N.M. Artemov on the basis of the Lepidoptera card index of the Gorkovskaya Oblast (former name of the Nizhny Novgorod Region). Collection of Lepidoptera of S.S. Chetverikov is currently stored in the Zoological Institute of the Russian Academy of Sciences (St. Petersburg, Russia).

Unfortunately, practically no information has survived about the collectors who sampled Lepidoptera and lived earlier in the Nizhny Novgorod Region, P.A. Pokrovsky, Yu. Ulyanov, Yu. Pisarev, L. Uspensky, and some others. Their materials are currently stored in the collections of the Zoological Museum of N.I. Lobachevsky Nizhny Novgorod State University (Nizhny Novgorod, Russia). At the end of the XX - beginning of the XXI century, Yu.B. Kosarev, a recognized specialist in local fauna of Lepidoptera, collected a large collection of butterflies (more than 7000 specimens), which comprised all species of diurnal butterflies of the Nizhny Novgorod Region. $\mathrm{He}$ also took part in writing of the section "Insects" of the Red List of the Nizhny Novgorod Region (author of 23 species sketches) and supplemented the list of Rhopalocera of the region, compiled by S.S. Chetverikov (Korb and Kosarev, 1993).

Recently, a great contribution to the study of the fauna of diurnal butterflies of the region was made by A.A. Zatakovoy, D.A. Pozhogin, R.E. Tal'yak, E.V. Martyanova, and A.A. Rogachev. The author was able to analyze their collections in whole or in part. In turn, the author published a number works on butterflies of the Nizhny Novgorod region, their ecology and protection (Korb and Kosarev, 1993; Korb, 1993, 1994, 1995a, 1995b, 2000a, 2000b, 2002, 2003, 2006, 2011a; 2011b, 2012, 2013a, 2013b, 2013c, 2014; Korb et al., 2011, 2012).

The study aims to analyze the dynamics of the gamma diversity of the fauna of diurnal butterflies of the Nizhny Novgorod Region over a hundred-year period (from 1903 till present) and to predict possible changes in the fauna in the future.

\section{Materials and methods}

The published data and the materials from the collections of the Zoological Museum and the Department of Botany and Zoology of N.I. Lobachevsky Nizhny Novgorod University, the Zoological Institute of the Russian Academy of Sciences, as well as from private collections of Yu.B. Kosarev, D.A. Pozhogin, A.A. Zatakovoy, E.V. Martyanova, A.A. Rogachev (Nizhny Novgorod) and R.E. Tal'yak (Dzerzhinsk), personal communications with collectors (especially valuable data was presented by Yu.B. Kosarev) and own observations and collections (from 1988 to 2016) were analyzed.

The abundance of butterflies was estimated using the gradation scale of B.L. Manin and L.N. Mazin (1976). Data from previous publications have been extrapolated in accordance to this scale.

\section{Results}

The data volume on the gamma diversity of diurnal butterflies of the Nizhny Novgorod Region has been increasing over the past 100 years: in 1906, 103 species were known in the local fauna (Yakhontov, 1906), in 1935-1993, their number increased up to 116 species (Chetverikov, 1993). An intermittent growth in the species number was due to the studies performed since 1990s: in 1993, 13 species have been added to the fauna at once to the list compiled by S.S. Chetverikov (up to 133 species: Korb and Kosarev, 1993); in 2006, 145 species have been already listed (Korb, 2006). Finally, the latest additions were made in 2010-2014 (Korb et al., 2012; Mukhanov, 2010, 2014), so another 5 species have been added, currently amounting to 150 species.

Table 1 summarizes the data on the dynamics of the abundance of butterflies over the period under consideration. Based on these data, the entire fauna may be divided into four groups:

Group I. Species with stable abundance. This group includes Papilio machaon, Parnassius apollo, Driopa mnemosyne, Leptidea sinapis, L. juvernica, L. morsei, Anthocharis cardamines, Pieris brassicae, Aporia crataegi, Pontia daplidice, P. chloridice, Colias hyale, C. erate, C. chrysotheme, C. mirmydone, Gonepteryx rhamni, Lasiommata maera, L. petropolitana, Lopinga achine, Pararge aegeria, Chortobius pamphiIus, C. tullia, C. glycerion, C. hero, Erebia aethiops, E. embla, E. medusa, E. euryale, Oeneis jutta, O. tarpeia, Hyponephele lycaon, $H$. lupina, Aphantopus hyperanthus, Minois dryas, Chazara briseis, Neptis sappho, N. rivularis, Limenitis populi, L. camilla, Apatura ilia, A. iris, Araschnia levana, Polygonia c-album, Aglais urticae, Nymphalis xanthomelas, Inachis io, Vanessa cardui, V. atalanta, Argynnis adippe, A. niobe, A. paphia, A. aglaja, Issoria lathonia, Brenthis ino, Boloria dia, B. titania, B. thore, B. euphrosyne, B. selene, $B$. selenis, Euphydryas maturna, E. aurinia, Mellicta athalia, M. aurelia, M. britomartis, Melitaea diamina, M. cinxia, M. didyma, M. trivia, M. phoebe, Neozephyrus quercus, Fixsenia spini, F. ilicis, F. pruni, F. w-album, Callophrys rubi, Neolycaena rhymnus, Lycaena tityrus, L. virgaureae, L. alciphron, L. hippothoe, Cupido alcetas, C. argiades, Celastrina argiolus, 
Table 1. Dynamics of the abundance and species composition of the fauna of butterflies of the Nizhny Novgorod Region. Study periods: I - 1906 (Yakhontov, 1906); II - 1935-1937 (Chetverikov, 1993); III - 1965-1970 (data by Yu.B. Kosarev); IV - 1993 (Korb and Kosarev, 1993; original data; observers' data, see section 'Acknowledgments'); V - 2006 (Korb, 2006; original data; observers' data); VI -20102012 (Korb et al., 2011, 2012; Mukhanov, 2010, 2014; original data; observers' data). Abundance scores: 1 - single species, 2 - rare species, 3 - common species, 4 - abundant species, 5 - background species (Manin and Mazin, 1976). "+" - no information about the species abundance for a specific period is available; "-" - species not registered at a particular stage of study.

\begin{tabular}{|c|c|c|c|c|c|c|}
\hline \multirow{2}{*}{ Species } & \multicolumn{6}{|c|}{ Study periods } \\
\hline & 1 & II & III & IV & $\mathrm{V}$ & $\mathrm{VI}$ \\
\hline Papilio machaon Linnaeus, 1758 & 4 & + & 4 & 4 & 4 & 4 \\
\hline Iphiclides podalirius (Linnaeus, 1758) & 3 & + & 3 & 4 & 4 & 4 \\
\hline Parnassius apollo (Linnaeus, 1758) & + & + & 1 & 1 & 1 & 1 \\
\hline Driopa mnemosyne (Linnaeus, 1758) & + & + & 4 & 4 & 4 & 4 \\
\hline Zerynthia polyxena (Denis et Schiffermüller, 1775) & - & + & 1 & 2 & 2 & 3 \\
\hline Leptidea sinapis (Linnaeus, 1758) & 4 & + & 4 & 4 & 4 & 4 \\
\hline L. juvernica Williams, 1948 & - & - & - & - & - & 4 \\
\hline L. morsei (Fenton, 1881) & - & - & - & 2 & 2 & 2 \\
\hline Anthocharis cardamines (Linnaeus, 1758) & 4 & + & 4 & 4 & 4 & 4 \\
\hline Euchloe ausonia (Hübner, 1805) & - & - & - & - & 1 & 2 \\
\hline Pieris napi (Linnaeus, 1758) & 4 & + & 4 & 4 & 5 & 5 \\
\hline P. rapae (Linnaeus, 1758) & 4 & + & 4 & 5 & 5 & 5 \\
\hline P. brassicae (Linnaeus, 1758) & 4 & + & 4 & 4 & 4 & 4 \\
\hline Aporia crataegi (Linnaeus, 1758) & 4 & + & 4 & 4 & 4 & 4 \\
\hline Pontia daplidice (Linnaeus, 1758) & 4 & + & 4 & 4 & 4 & 4 \\
\hline Pontia chloridice (Hübner, 1813) & 1 & + & - & 1 & 1 & 1 \\
\hline Colias hyale (Linnaeus, 1758) & 4 & + & 4 & 4 & 4 & 4 \\
\hline C. alfacariensis Ribbe, 1905 & - & - & - & - & 2 & 3 \\
\hline C. palaeno (Linnaeus, 1761) & + & + & 2 & 2 & 3 & 3 \\
\hline C. erate (Esper, 1801) & + & + & 1 & 1 & 1 & 1 \\
\hline C. chrysotheme (Esper, 1781) & - & + & 1 & 1 & 1 & 1 \\
\hline C. mirmydone (Esper, 1781) & 4 & + & 4 & 4 & 4 & 4 \\
\hline Gonepteryx rhamni (Linnaeus, 1758) & + & + & 4 & 4 & 4 & 4 \\
\hline Lasiommata maera (Linnaeus, 1758) & + & + & 4 & 4 & 4 & 4 \\
\hline L. petropolitana (Fabricius, 1787) & + & + & 4 & 4 & 4 & 4 \\
\hline Lopinga achine (Scopoli, 1761) & + & + & 4 & 4 & 4 & 4 \\
\hline Pararge aegeria (Linnaeus, 1758) & - & - & - & - & 1 & 1 \\
\hline Melanargia russiae (Esper, 1783) & - & - & - & 1 & 2 & 4 \\
\hline M. galathea (Linnaeus, 1758) & - & - & - & - & - & 2 \\
\hline Chortobius pamphilus (Linnaeus, 1758) & 4 & + & 4 & 4 & 4 & 4 \\
\hline C. tullia (Müller, 1764) & 4 & + & 4 & 4 & 4 & 4 \\
\hline C. glycerion (Borkhausen, 1788) & 4 & + & 4 & 4 & 4 & 4 \\
\hline C. leander (Esper, 1784) & - & - & - & - & 1 & 1 \\
\hline C. arcania (Linnaeus, 1761) & - & - & - & 3 & 3 & 2 \\
\hline
\end{tabular}




\begin{tabular}{|c|c|c|c|c|c|c|}
\hline \multirow{2}{*}{ Species } & \multicolumn{6}{|c|}{ Study periods } \\
\hline & 1 & II & III & IV & $\mathrm{V}$ & VI \\
\hline C. hero (Linnaeus, 1761) & 4 & + & 4 & 4 & 4 & 4 \\
\hline Erebia aethiops (Esper, 1777) & - & + & 1 & 1 & 1 & 1 \\
\hline E. embla (Thunberg, 1791) & - & + & - & 1 & 1 & 1 \\
\hline E. ligea (Linnaeus, 1758) & + & + & 2 & 3 & 3 & 4 \\
\hline E. medusa (Denis et Schiffermüller, 1775) & - & - & 1 & - & 1 & 1 \\
\hline E. euryale (Esper, 1805) & - & - & 1 & 1 & 1 & 1 \\
\hline Oeneis jutta (Hübner, 1806) & - & + & 1 & 1 & 1 & 1 \\
\hline Oeneis tarpeia (Pallas, 1771) & + & + & 2 & 2 & 2 & 2 \\
\hline Maniola jurtina (Linnaeus, 1758) & 4 & + & 4 & 5 & 5 & 5 \\
\hline Hyponephele lycaon (Rottemburg, 1775) & 4 & + & 4 & 4 & 4 & 4 \\
\hline H. lupina (Costa, 1836) & - & - & - & 1 & 1 & 1 \\
\hline Aphantopus hyperanthus (Linnaeus, 1758) & 4 & + & 4 & 4 & 4 & 4 \\
\hline Minois dryas (Scopoli, 1761) & 2 & + & 2 & 2 & 2 & 2 \\
\hline Chazara briseis (Linnaeus, 1764) & 1 & + & - & 1 & 1 & 1 \\
\hline Hipparchia autonoe (Esper, 1783) & - & - & - & - & 1 & 1 \\
\hline Pseudochasara hippolyte (Esper, 1784) & - & - & - & - & 1 & 1 \\
\hline Satyrus ferula (Fabricius, 1793) & - & - & - & 1 & 1 & 1 \\
\hline Neptis sappho (Pallas, 1771) & 4 & + & 4 & 4 & 4 & 4 \\
\hline N. rivularis (Scopoli, 1761) & - & + & 4 & 4 & 4 & 4 \\
\hline Limenitis populi (Linnaeus, 1758) & 4 & + & 4 & 4 & 4 & 4 \\
\hline L. camilla (Linnaeus, 1764) & 4 & + & 4 & 4 & 4 & 4 \\
\hline Apatura ilia (Denis et Schiffermüller, 1775) & 3 & + & 4 & 4 & 4 & 4 \\
\hline A. iris (Linnaeus, 1758) & - & + & 4 & 4 & 4 & 4 \\
\hline Araschnia levana (Linnaeus, 1758) & + & + & 4 & 4 & 4 & 4 \\
\hline Polygonia c-album (Linnaeus, 1758) & 3 & + & 4 & 4 & 4 & 4 \\
\hline Aglais urticae (Linnaeus, 1758) & 4 & + & 4 & 4 & 4 & 4 \\
\hline Nymphalis xanthomelas (Denis et Schiffermüller, 1775) & 3 & + & 4 & 4 & 4 & 4 \\
\hline N. polychloros (Linnaeus, 1758) & - & + & 3 & 2 & 2 & 1 \\
\hline N. vau-album (Denis et Schiffermüller, 1775) & 3 & + & 3 & 3 & 3 & 4 \\
\hline N. antiopa (Linnaeus, 1758) & 3 & + & 3 & 2 & 2 & 1 \\
\hline Inachis io (Linnaeus, 1758) & 4 & + & 4 & 4 & 4 & 4 \\
\hline Vanessa cardui (Linnaeus, 1758) & 4 & + & 4 & 4 & 4 & 4 \\
\hline V. atalanta (Linnaeus, 1758) & 4 & + & 4 & 4 & 4 & 4 \\
\hline Argynnis adippe (Rottemburg, 1775) & 4 & + & 4 & 4 & 4 & 4 \\
\hline A. niobe (Linnaeus, 1758) & 4 & + & 4 & 4 & 4 & 4 \\
\hline A. paphia (Linnaeus, 1758) & 4 & + & 4 & 4 & 4 & 4 \\
\hline A. laodice (Pallas, 1771) & + & + & 1 & 1 & 2 & 2 \\
\hline A. aglaja (Linnaeus, 1758) & 4 & + & 4 & 4 & 4 & 4 \\
\hline Issoria lathonia (Linnaeus, 1758) & 4 & + & 4 & 4 & 4 & 5 \\
\hline
\end{tabular}




\begin{tabular}{|c|c|c|c|c|c|c|}
\hline \multirow{2}{*}{ Species } & \multicolumn{6}{|c|}{ Study periods } \\
\hline & 1 & II & III & IV & $\mathrm{V}$ & VI \\
\hline Brenthis ino (Rottemburg, 1775) & 4 & + & 4 & 4 & 4 & 4 \\
\hline B. daphne (Denis et Schiffermüller, 1775) & - & - & 1 & 1 & - & 2 \\
\hline Boloria aquilonaris (Stichel, 1908) & 4 & - & - & - & 4 & 4 \\
\hline B. dia (Linnaeus, 1758) & 4 & + & 4 & 4 & 4 & 4 \\
\hline B. titania (Esper, 1793) & 4 & + & 4 & 4 & 4 & 4 \\
\hline B. thore (Hübner, 1803) & - & - & 1 & 1 & 1 & 1 \\
\hline B. euphrosyne (Linnaeus, 1758) & 4 & + & 4 & 4 & 4 & 4 \\
\hline B. selene (Denis et Schiffermüller, 1775) & 4 & + & 4 & 4 & 4 & 4 \\
\hline B. selenis (Eversmann, 1837) & - & + & - & 1 & 1 & 1 \\
\hline B. eunomia (Esper, 1799) & 2 & + & - & 1 & 1 & 1 \\
\hline B. freija (Thunberg, 1791) & - & - & - & - & - & 1 \\
\hline Euphydryas maturna (Linnaeus, 1758) & + & + & 3 & 3 & 3 & 3 \\
\hline E. aurinia (Rottemburg, 1775) & + & + & 3 & 3 & 3 & 3 \\
\hline Mellicta athalia (Rottemburg, 1775) & 4 & + & 4 & 4 & 4 & 4 \\
\hline M. aurelia (Nickerl, 1850) & 2 & + & 2 & 2 & 2 & 2 \\
\hline M. britomarthis (Assman, 1847) & 1 & + & - & 1 & 1 & 1 \\
\hline Melitaea diamina (Lang, 1789) & 4 & + & 4 & 4 & 4 & 4 \\
\hline M. cinxia (Linnaeus, 1758) & + & + & 4 & 4 & 4 & 4 \\
\hline M. didyma (Esper, 1779) & 4 & + & 4 & 4 & 4 & 4 \\
\hline M. trivia (Denis et Schiffermüller, 1775) & - & - & - & 1 & 1 & 1 \\
\hline M. phoebe (Denis et Schiffermüller, 1775) & + & + & 4 & 4 & 4 & 4 \\
\hline Thecla betulae (Linnaeus, 1758) & + & + & 3 & 3 & 3 & 4 \\
\hline Neozephyrus quercus (Linnaeus, 1758) & + & + & 2 & 2 & 2 & 2 \\
\hline Fixsenia spini (Denis et Schiffermüller, 1775) & - & + & 4 & 4 & 4 & 4 \\
\hline N. ilicis (Esper, 1779) & + & + & 4 & 4 & 4 & 4 \\
\hline N. pruni (Linnaeus, 1758) & + & + & 4 & 4 & 4 & 4 \\
\hline N. w-album (Knoch, 1782) & + & + & 4 & 4 & 4 & 4 \\
\hline Callophrys rubi (Linnaeus, 1758) & + & + & 4 & 4 & 4 & 4 \\
\hline Neolycaena rhymnus (Eversmann, 1832) & - & - & - & - & 1 & 1 \\
\hline Lycaena phlaeas (Linnaeus, 1761) & 4 & + & 4 & 4 & 5 & 5 \\
\hline L. helle (Denis et Schiffermüller, 1775) & + & + & 1 & 1 & 2 & 2 \\
\hline L. tityrus (Poda, 1761) & 4 & + & 4 & 4 & 4 & 4 \\
\hline L. virgaureae (Linnaeus, 1758) & 4 & + & 4 & 4 & 4 & 4 \\
\hline L. dispar (Haworth, 1802) & 3 & + & 3 & 3 & 2 & 2 \\
\hline L. alciphron (Rottemburg, 1775) & + & + & 2 & 2 & 2 & 2 \\
\hline L. hippothoe (Linnaeus, 1758) & 3 & + & 4 & 4 & 4 & 4 \\
\hline Cupido alcetas (Hoffmannsegg, 1804) & 4 & + & 4 & 4 & 4 & 4 \\
\hline C. argiades (Pallas, 1771) & 3 & + & 3 & 3 & 3 & 3 \\
\hline C. minimus (Fuessly, 1775) & - & - & - & - & 2 & 2 \\
\hline
\end{tabular}




\begin{tabular}{|c|c|c|c|c|c|c|}
\hline \multirow{2}{*}{ Species } & \multicolumn{6}{|c|}{ Study periods } \\
\hline & I & II & III & IV & $\mathrm{V}$ & VI \\
\hline Celastrina argiolus (Linnaeus, 1758) & 4 & + & 4 & 4 & 4 & 4 \\
\hline Glaucopsyche alexis (Poda, 1761) & 3 & + & 4 & 3 & 2 & 3 \\
\hline Scolitantides orion (Pallas, 1771) & + & + & 1 & 1 & 1 & 1 \\
\hline Phengaris alcon (Denis et Schiffermüller, 1775) & 2 & + & 1 & 1 & 2 & 3 \\
\hline P. nausithous (Bergsträsser, 1779) & - & - & 1 & 1 & 2 & 2 \\
\hline P. teleius (Bergsträsser, 1779) & - & - & 1 & 1 & 2 & 2 \\
\hline P. arion (Linnaeus, 1758) & - & + & 1 & 1 & 1 & 1 \\
\hline Plebeius idas (Linnaeus, 1761) & - & - & 1 & 1 & 2 & 2 \\
\hline P. argus (Linnaeus, 1758) & 3 & + & 4 & 4 & 4 & 5 \\
\hline P. argyrognomon (Bergsträsser, 1779) & 4 & + & 4 & 4 & 5 & 5 \\
\hline P. maracandicus (Erschoff, 1874) & - & - & - & - & - & 2 \\
\hline Vacciniina optilete (Knoch, 1781) & + & + & 4 & 4 & 4 & 4 \\
\hline Polyommatus icarus (Rottemburg, 1775) & 4 & + & 4 & 4 & 4 & 4 \\
\hline P. thersites (Cantener, 1834) & - & - & 2 & 2 & 2 & 2 \\
\hline P. eros (Ochsenheimer, 1808) & 3 & + & 1 & 1 & 1 & 1 \\
\hline P. amandus (Schneider, 1782) & 3 & + & 4 & 4 & 4 & 4 \\
\hline P.bellargus (Rottemburg, 1775) & - & - & 1 & - & 1 & 1 \\
\hline P. coridon (Poda, 1761) & - & - & 1 & 1 & 1 & 1 \\
\hline P. eumedon (Esper, 1780) & 4 & + & 4 & 4 & 4 & 4 \\
\hline P. dorylas (Denis et Schiffermüller, 1775) & - & - & 1 & - & 1 & 1 \\
\hline Cyaniris semiargus (Rottemburg, 1775) & 4 & + & 4 & 4 & 4 & 4 \\
\hline Aricia agestis (Denis et Schiffermüller, 1775) & 4 & + & 2 & 2 & 2 & 2 \\
\hline A. artaxerxes (Fabricius, 1793) & - & - & 4 & 4 & 4 & 4 \\
\hline Hesperia comma (Linnaeus, 1758) & 4 & + & 3 & 3 & 2 & 1 \\
\hline H. sylvana (Esper, 1777) & 4 & + & 4 & 4 & 4 & 4 \\
\hline Thymelicus lineola (Ochsenheimer, 1808) & 3 & + & 4 & 4 & 4 & 4 \\
\hline T. sylvestris (Poda, 1761) & 4 & + & 3 & 3 & 2 & 2 \\
\hline Carterocephalus palaemon (Pallas, 1771) & + & + & 4 & 4 & 4 & 4 \\
\hline C. silvicolus (Meigen, 1829) & 3 & + & 3 & 3 & 3 & 1 \\
\hline Heteropterus morpheus (Pallas, 1771) & - & - & 1 & - & 1 & 1 \\
\hline Erynnis tages (Linnaeus, 1758) & - & + & 1 & 2 & 2 & 4 \\
\hline Carcharodus alceae (Esper, 1780) & + & - & 1 & 1 & 2 & 4 \\
\hline C. flocciferus (Zeller, 1847) & - & + & - & 1 & 1 & 1 \\
\hline Muschampia tessellum (Hübner, 1803) & - & + & - & 2 & 2 & 2 \\
\hline Pyrgus malvae (Linnaeus, 1758) & 4 & + & 4 & 4 & 4 & 4 \\
\hline P. alveus (Hübner, 1803) & 4 & + & - & 2 & 2 & 1 \\
\hline P. cinarae (Rambur, 1839) & - & - & - & 1 & 1 & 1 \\
\hline P. serratulae (Rambur, 1839) & - & + & - & 1 & 1 & 1 \\
\hline Total & 103 & 116 & 120 & 133 & 145 & 149 \\
\hline
\end{tabular}


Scolitantides orion, Phengaris arion, Vacciniina optilete, Polyommatus icarus, $P$. thersites, P. amandus, $P$. bellargus, P. coridon, P. dorylas, P. eumedon, Cyaniris semiargus, Aricia artaxerxes, Hesperia sylvana, Carterocephalus palaemon, Heteropterus morpheus, Carcharodus flocciferus, Syrichtus tessellum, Pyrgus malvae, $P$. cinarae, $P$. serratulae.

Group II. Species with increasing abundance. These are: Iphiclides podalirius, Zerynthia polyxena, Euchloe ausonia, Pieris napi, P. rapae, Colias alfacariensis, C. palaeno, Melanargia russiae, M. galathea, Chortobius leander, C. arcania, Erebia ligea, Maniola jurtina, Hipparchia autonoe, Pseudochasara hippolyte, Satyrus ferula, Nymphalis vau-album, Argynnis laodice, Brenthis daphne, Boloria aquilonaris, Thecla betulae, Lycaena phlaeas, L. helle, Cupido minimus, Phengaris nausithous, P. teleius, Plebeius idas, P. argus, P. argyrognomon, P. maracandicus, Thymelicus lineola, Erynnis tages, Carcharodus alceae.

Group III. Species with decreasing abundance. These are: Nymphalis polychloros, N. antiopa, Boloria eunomia, B. freija, Lycaena dispar, Glaucopsyche alexis, Polyommatus eros, Aricia agestis, Hesperia comma, Thymelicus sylvestris, Carterocephalus silvicolus, Pyrgus alveus.

Group IV. Species with fluctuating abundance, presented by Phengaris alcon.

\section{Discussion}

The positive dynamics of the species composition of butterflies of the Nizhny Novgorod region, apparently, is explained by three reasons:

1. Expansion of the area of fauna research from the environs of Nizhny Novgorod city (Yakhontov, 1906) both to the northern part of the region (taiga), and to its southern part (forest-steppe). This made it possible to discover and to include species that were not typical for the middle part of the region, which, in turn, has been seriously altered as a result of human activity. For example, Chortobius leander and Neolycaena rhymnus, found in the steppe ravines of the Knyagininsky District, Polyommatus dorylas and $P$. bellargus, found in the steppe meadows of the Arzamas District, Boloria thore and $B$. freija from the taiga massifs of the Tonshaevsky and Shakhunsky District, and some others, have never been recorded in the vicinity of Nizhny Novgorod city.

2. The general development of taxonomy and the use of new diagnostic methods allowed to identify the species that were previously mixed. In particular, this is true for the pair of sibling species Leptidea sinapis - L. juvernica (Dincă et al., 2011).

3. Natural expansion of ranges of some species due to changes in climatic conditions and/or due to human economic activity. For example, both representatives of the genus Melanargia Meigen, 1820 are the species of diurnal butterflies that have entered the region relatively recently.
One hundred and four species form a stable core of the diurnal butterflies' fauna of the Nizhny Novgorod region. Thirty-three species have increased abundance during the last 110 years, twelve species have a tendency to decrease their abundances, and one species has a fluctuating number.

Special attention must be paid to the species with a decreasing abundance in order to analyze the reasons for such a decline. The southern margin of the ranges of arcto-boreal species (Boloria eunomia, B. freija, and Carterocephalus silvicolus) is apparently shifting northwards due to the general climate warming, and the area inhabited by these species in the Nizhny Novgorod Region, is shrinking. The same is true for boreal species (Nymphalis antiopa, Glaucopsyche alexis, Hesperia comma, and Thymelicus sylvestris, when the number of their habitats decreases as well mainly due to climate warming.

Another group of species with a declining abundance is the group of steppe species (Lycaena dispar, Aricia agestis, Polyommatus eros, and Pyrgus alveus). Unlike xerophilic species, such as Melanargia russiae or $M$. galathea, which spread widely to the north in a warming climate, steppe species are dependent on biotopes that are disturbed by human economic activity.

The reasons for the decrease in the abundance of Nymphalis polychloros in the Nizhny Novgorod Region are still unclear.

It is also important to note the Rhopalocera species with a consistently low abundance as the most vulnerable components of the Nizhny Novgorod fauna. These are Parnassius apollo, Colias erate, C. chrysotheme, Pararge aegeria, Chortobius leander, Erebia aethiops, E. embla, E. medusa, E. euryale, Oeneis jutta, Hyponephele lupina, Chazara briseis, Hipparchia autonoe, Pseudochazara hippolyte, Satyrus ferula, Boloria selenis, Melitaea britomarthis, Neolycaena rhymnus, Scolitantides orion, Phengaris arion, Polyommatus bellargus, P. coridon, P. dorylas, Heteropterus morpheus, Carcharodus flocciferus, Pyrgus cinarae, and $P$. serratulae. Most of them are steppe species found in the region over the past 25 years. The data on the long-term abundance dynamics of these species has not yet been accumulated. In order to do so, their constant monitoring is required; however, taking into account the information on other steppe species available for analysis (original data), it is possible to predict a decrease in the abudance of Colias erate, C. chrysotheme, Chortobius leander, Erebia aethiops, E. medusa, Hyponephele lupina, Chazara briseis, Hipparchia autonoe, Pseudochazara hippolyte, Satyrus ferula, Boloria selenis, Melitaea britomarthis, Neolycaena rhymnus, Phengaris arion, Polyommatus bellargus, $P$. coridon, $P$. dorylas, Carcharodus flocciferus, Pyrgus cinarae, and P. serratulae. For the same reason, a decrease in the abundance of 
arcto-boreal Erebia embla, E. euryale, and Oeneis jutta is also highly probable. Almost all of the above species are stenotopic inhabitants of steppe and steppe-transforming habitats (the first 20 species) or sphagnum bogs (the last 3 species); all of them very sensitive to disturbance of their biotopes.

The dynamics of the gamma diversity of butterflies of the regions of Russia has not been previously studied in a historical perspective; i.e. our research is the first one. Practically, it is extremely important for long-term forecasting of changes in the abundance of Rhopalocera species based on the tracked multiyear dynamics. This makes it possible to compile the lists of protected species and to plan forthcoming protection measures more reasonably.

Unfortunately, such data is not available for all the constituent entities of the Russian Federation. However, the extrapolation of our conclusions for regions with similar conditions (Kirov, Ivanovsk, Vladimir, Kostroma, Penza, and Ulyanovsk regions and the Republic of Mari El, Chuvash Republic, and Mordovia), taking into account the natural conditions of these areas, seems applicable and quite promising.

\section{Conclusions}

1. The hundred-year dynamics of gamma diversity and butterflies' abundance have been assessed for the first time in Russia for the Nizhny Novgorod Region.

2. In the near future, no significant change is expected in the abundance of 104 species of diurnal butterflies of the Nizhny Novgorod region.

3. The abundance of 33 species is likely to increase in the near future.

4. The abundance of 12 species of diurnal butterflies (Nymphalis polychloros, N. antiopa, Boloria eunomia, B. freija, Lycaena dispar, Glaucopsyche alexis, Polyommatus eros, Aricia agestis, Hesperia comma, Thymelicus sylvestris, and Carterocephalus silvicolus) will continue to decrease. Some of these species are already included into the Red List of the Nizhny Novgorod Region, some are recommended for listing. The species with fluctuating abundance (Phengaris alcon) is also included in the Red List of the Nizhny Novgorod Region.

5. The abundances of Colias erate, C. chrysotheme, Chortobius leander, Erebia aethiops, E. medusa, E. embla, E. euryale, Oeneis jutta, Hyponephele lupina, Chazara briseis, Hipparchia autonoe, Pseudochazara hippolyte, Satyrus ferula, Boloria selenis, Melitaea britomarthis, Neolycaena rhymnus, Phengaris arion, and Polyommatus floratus floratus, steppe and arcto-boreal diurnal butterflies, are predicted to decrease in the Nizhny Novgorod Region.

6. The results of this study can be extrapolated to the faunas of the regions of Russia adjacent to the Nizhny Novgorod region in order to predict long-term changes in Lepidoptera fauna in these areas.

\section{Acknowledgments}

The author expresses the deepest gratitude to all colleagues, Yu.B. Kosarev, D.A. Pozhogin, A.A. Zatakovoy, E.V. Martyanova, and A.A. Rogachev, who provided the material for analysis and who took part in the expedition together with the author. Special thanks go to G.A. Anufriev (N.I. Lobachevsky Nizhny Novgorod State University) for comprehensive support and assistance in conducting research in the region, as well as for supporting the access to the Lepidoptera collections stored at the Department of Zoology, Biological Station, and in the Zoological Museum of Nizhny Novgorod State University. The authors is grateful to S.Yu. Sinev and A.L. Lvovsky for providing the access to the collections stored at the Zoological Institute of the Russian Academy of Sciences.

\section{ORCID}

S.K. Korb (ID 0000-0002-1120-424X

\section{References}

Chetverikov, S.S., 1993. Babochki Gor'kovskoy oblasti [Butterflies of the Gorkovskaya Oblast]. Nizegorodsky State University, Nizhny Novgorod, Russia, 128 p. (In Russian).

Dincă, V., Lukhtanov, V.A., Talavera, G., Vila, R., 2011. Unexpected layers of cryptic diversity in wood white Leptidea butterflies. Nature Communications 2 (324). https://doi.org/10.1038/ncomms1329

Korb, S.K., 1993. Redkiye cheshuyekrylyye na stepnykh uchastkakh Nizhegorodskoy oblasti, predlagayemyye $k$ okhrane $v$ kachestve pamyatnikov prirody [Rare Lepidoptera in the steppe areas of the Nizhny Novgorod region, proposed for protection as natural monuments]. Tezisy dokladov IV nauchnoy konferentsii "Problemy issledovaniya pamyatnikov istorii, kul'tury i prirody yevropeyskoy Rossii" [Abstracts of the IV scientific conference "Problems of research of monuments of history, culture and nature of European Russia"]. Nizhny Novgorod, Russia, 58-59. (In Russian).

Korb, S.K., 1994. Ekologiya Driopa Mnemosyne L. v Nizhegorodskoy oblasti, redkogo vida parusnikov, zanesennogo $v$ Krasnuyu knigu SSSR [Ecology of Driopa Mnemosyne L. in the Nizhny Novgorod region, a rare species of swallowtail butterfly listed in the Red List of the USSR]. Tezisy dokladov $V$ nauchnoy konferentsii "Problemy issledovaniya pamyatnikov istorii, kul'tury i prirody yevropeyskoy Rossii" [Abstracts of the IV scientific conference "Problems of research of monuments of history, culture and nature of European Russia"]. Nizhny Novgorod, Russia, 98-99. (In Russian). 
Korb, S.K., 1995a. Dnevnyye babochki (Lepidoptera, Rhopalocera), sobrannyye $v$ gosudarstvennom prirodnom zapovednike "Kerzhenskiy" v avguste 1994 goda [Daytime butterflies (Lepidoptera, Rhopalocera) collected in the Kerzhensky State Nature Reserve in August 1994]. Tezisy dokladov VI nauchnoy konferentsii "Problemy issledovaniya pamyatnikov istorii, kul'tury i prirody yevropeyskoy Rossii" [Abstracts of the IV scientific conference "Problems of research of monuments of history, culture and nature of European Russia"]. Nizhny Novgorod, Russia, 66-67. (In Russian).

Korb, S.K., 1995b. Bulavousyye cheshuyekrylyye (Lepidoptera, Rhopalocera) s loka"nym rasprostraneniyem kak ob'yekty, nuzhdayushchiyesya $v$ okhrane $v$ Nizhegorodskoy oblasti [Butterflies (Lepidoptera, Rhopalocera) with local distribution as objects in need of protection in the Nizhny Novgorod region]. Tezisy dokladov VI nauchnoy konferentsii "Problemy issledovaniya pamyatnikov istorii, kul'tury i prirody yevropeyskoy Rossii" [Abstracts of the IV scientific conference "Problems of research of monuments of history, culture and nature of European Russia"]. Nizhny Novgorod, Russia, 67-68. (In Russian).

Korb, S.K., 2000a. Complement a la liste des Rhopaloceres de la region de Nijnii-Novgorod (Russie) (Lepidoptera Rhopalocera). Alexanor 21 (1), 38-40.

Korb, S.K., 2000b. Remarques sur la systématique et la repartition des Lycènes paléarctiques (II) (Lepidoptera Lycaenidae). Bulletin de la Société entomologique de Mulhouse 56 (3), 46-48. (In French).

Korb, S.K., 2002. Golubyanki gruppy Polyommatus eros (Lepidoptera, Lycaenidae): neskol'ko zametok [Gossamer-winged butterflies of Polyommatus eros group (Lepidoptera, Lycaenidae): a few notes]. Zoologicheskiy zhurnal [Zoological Journal] 81 (11), 1402-1405. (In Russian).

Korb, S.K., 2003. Notes sur la systematique et la repartition des Lycenes palearctiques (III) (Lepidoptera Lycaenidae). Bulletin de la Société entomologique de Mulhouse 59 (3), 46-48. (In French).

Korb, S.K., 2006. Dnevnyye babochki (Lepidoptera: Rhopalocera) Nizhegorodskoy oblasti [Diurnal butterflies (Lepidoptera: Rhopalocera) of the Nizhny Novgorod region]. Byulleten' Moskovskogo Obshchestva Ispytatelei Prirody. Otdel Biologicheskii [Bulletin of Moscow Society of Naturalists. Biological series] 111 (4), 8-14. (In Russian).

Korb, S.K., 2011a. Utochneniya i dobavleniya k perechnyu redkikh bulavousykh cheshuyekrylykh (Lepidoptera, Rhopalocera) Nizhegorodskoy oblasti [Clarifications and additions to the list of rare butterflies (Lepidoptera, Rhopalocera) of the Nizhny Novgorod Region]. In: Anufriyev, G.A. et al. (eds.), Redkiye vidy zhivykh organizmov Nizhegorodskoy oblasti: Sbornik rabochikh materialov Komissii po Krasnoy knige Nizhegorodskoy oblasti. Vyp. 2 [Rare species of living organisms of the Nizhny Novgorod region: Collection of working materials of the Commission for the Red List of the Nizhny Novgorod Region. Is. 2]. Ministry of Ecology and Natural Resources of the Nizhny Novgorod Region, Nizhny Novgorod, Russia, 82-91. (In Russian).

Korb, S.K., 2011b. Obzor vidov podroda Maculinea van Eecke, 1915 roda Phengaris Doherty, 1891 (Lepidoptera: Lycaenidae) fauny Palearktiki [Review of species of the subgenus Maculinea van Eecke, 1915 of the genus Phengaris Doherty, 1891 (Lepidoptera: Lycaenidae) of the Palearctic fauna]. Eversmannia 27-28, 22-46. (In Russian).

Korb, S.K., 2012. Plebeius maracandicus (Erschoff, 1874) - novyy vid golubyanok (Lepidoptera, Lycaenidae) dlya Verkhnego Povolzh'ya [Plebeius maracandicus (Erschoff, 1874) is a new species of gossamer-winged butterflies (Lepidoptera, Lycaenidae) for the Upper Volga region]. In: Anikin, V.V., Popov, N.V. (eds.), Entomologicheskiye $i$ parazitologicheskiye issledovaniya $v$ Povolzh'ye. Sbornik nauchnykh trudov. Vyp. 10. [Entomological and parasitological research in the Volga region. Collection of scientific papers. Is. 10]. Saratov University Publishing House, Saratov, Russia, 98-99. (In Russian).

Korb, S.K., 2013a. K sistematike i rasprostraneniyu golubyanok roda Glaucopsyche Scudder, 1872 (Lepidoptera: Lycaenidae) [On the taxonomy and distribution of gossamer-winged butterflies of the genus Glaucopsyche Scudder, 1872 (Lepidoptera: Lycaenidae)]. Amurskiy zoologicheskiy zhurnal [Amur Zoological Journal] 5 (2), 177-179. (In Russian).

Korb, S.K., 2013b. Sezonnaya dinamika lyota bulavousykh cheshuyekrylykh (Lepidoptera, Rhopalocera) Nizhegorodskoy oblasti [Seasonal dynamics of swarming of butterflies (Lepidoptera, Rhopalocera) in the Nizhny Novgorod Region]. Lepidopterologicheskiy zhurnal [Lepidopterological Journal] 2 (1), 3-7. (In Russian). 
Korb, S.K., 2013c. Bulavousyye cheshuyekrylyye (Lepidoptera, Papilionoformes) stepnykh uchastkov Nizhegorodskoy oblasti [Butterflies (Lepidoptera, Papilionoformes) of the steppe areas of the Nizhny Novgorod region]. Sbornik statey mezhdunarodnoy nauchnoy konferentsii 'Lesostep' Vostochnoy Yevropy: struktura, dinamika i okhrana" [Collection of articles of the international scientific conference "Forest-steppe of Eastern Europe: structure, dynamics and protection"], Penza, June 10-13 2013. Penza, Russia, 310. (In Russian).

Korb, S.K., 2014. Annotirovannyy spisok cheshuyekrylykh (Lepidoptera) Nizhegorodskoy oblasti [Annotated list of Lepidoptera (Lepidoptera) of the Nizhny Novgorod region]. Lepidopterologicheskiy zhurnal [Lepidopterological Journal] 3 (1), 3-70. (In Russian).

Korb, S.K., Kosarev, Yu.B., 1993. Dopolneniya k faune bulavousykh cheshuyekrylykh (Lepidoptera, Rhopalocera) Nizhegorodskoy oblasti [Additions to the fauna of butterflies (Lepidoptera, Rhopalocera) of the Nizhny Novgorod region]. In: Artemov, N.M. (ed.), Babochki Gor'kovskoy oblasti [Butterflies of the Gorky Region]. Nizhny Novgorod University Publishing House, Nizhny Novgorod, Russia, 123-125. (In Russian).

Korb, S.K., Pozhogin, D.A., Zatakovoy, A.A., 2011. Aktual'nyye dannyye po makrocheshuyekrylym (Lepidoptera: Macrolepidoptera) dlya vklyucheniya $v$ Krasnuyu knigu Nizhegorodskoy oblasti [Actual data on Macrolepidoptera (Lepidoptera: Macrolepidoptera) for inclusion in the Red List of the Nizhny Novgorod Region]. In: Anufriyev, G.A. et al. (eds.), Redkiye vidy zhivykh organizmov Nizhegorodskoy oblasti: Sbornik rabochikh materialov Komissii po Krasnoy knige Nizhegorodskoy oblasti. Vyp. 2 [Rare species of living organisms of the Nizhny Novgorod region: Collection of working materials of the Commission for the Red List of the Nizhny Novgorod Region. Is. 2]. Ministry of Ecology and Natural Resources of the Nizhny Novgorod Region, Nizhny Novgorod, Russia, 106-125. (In Russian).

Korb, S.K., Pozhogin, D.A., Zatakovoy, A.A., Knyazev, S.A., 2012. Dopolneniya $k$ faune cheshuyekrylykh (Lepidoptera) Nizhegorodskoy oblasti [Additions to the Lepidoptera fauna of the
Nizhny Novgorod region]. Eversmannia 29-30, 42-49. (In Russian).

Manin, B.L., Mazin, L.N., $1976 . \quad$ Fonovyye bulavousyye cheshuyekrylyye podnival'nykh poyasov nekotorykh gornykh khrebtov SredneyAzii i Kazakhstana [Background butterflies of the subnival belts of some mountain ranges of Central Asia and Kazakhstan]. Tezisy vsesoyuznoy nauchnoy konferentsii zoologov pedvuzov "Sovremennyye problemy zoologii $i$ sovershenstvovaniye yeye prepodavaniya v vuze $i$ shkole"[ Abstracts of the All-Union Scientific Conference of Zoologists of Pedagogical Universities "Modern problems of zoology and the improvement of its teaching at the university and school"], Perm, September 13-16, 1976. Perm, USSR, 103-105 (In Russian).

Mukhanov, A.V., 2010. Galateya Melanargia galathea (Linnaeus, 1758) v Nizhegorodskoy oblasti [Marbled white Melanargia galathea (Linnaeus, 1758) in the Nizhny Novgorod Region]. In: Anufriyev, G.A. et al. (eds.), Redkiye vidy zhivykh organizmov Nizhegorodskoy oblasti: Sbornik rabochikh materialov Komissii po Krasnoy knige Nizhegorodskoy oblasti. Vyp. 2 [Rare species of living organisms of the Nizhny Novgorod region: Collection of working materials of the Commission for the Red List of the Nizhny Novgorod Region. Is. 2]. Ministry of Ecology and Natural Resources of the Nizhny Novgorod Region, Nizhny Novgorod, Russia, 106. (In Russian).

Mukhanov, A.V., 2014. Perlamutrovka sfagnovaya (freyya) - Clossiana freija Thunberg [Freija fritillary, Clossiana freija Thunberg]. In: Anufriyev, G.A. (ed.), Krasnaya kniga Nizhegorodskoy oblasti. T. 1. Zhivotnyye [Red List of the Nizhny Novgorod Region. V. 1. Animals]. Ministry of Ecology and Natural Resources, Nizhny Novgorod, Russia, 345-346. (In Russian).

Yakhontov, A.A., 1906. Materialy po faune Lepidoptera-Rhopalocera Vladimirskoy i Nizhegorodskoy guberniy [Materials on the Lepidoptera-Rhopalocera fauna of the Vladimir and Nizhny Novgorod provinces]. Materialy $k$ poznaniyu fauny i flory Rossiyskoy imperii. Otdel zoologicheskiy [Materials for the knowledge of the fauna and flora of the Russian Empire. Zoological Series] 7, 93-145 (In Russian). 